\title{
Creating a Trusted Public Organization Organizational Trust Analysis in Implementation Network of the Education Quality Assurance Policy in Indonesia
}

\author{
Alwi \\ Department of Administrative Science \\ Hasanuddin University, \\ Makassar, Indonesia \\ alwifisip@gmail.com
}

\author{
Mashuri H.Tahili \\ Faculty of Social and Political Sciences \\ Muhammadiyah University of Luwuk Banggai \\ Luwuk Bangai, Indonesia \\ mashuritahili1971@gmail.com
}

\begin{abstract}
The main purpose of this research is to analyze the perspective of organizational trust in the implementation network of education quality assurance policy in Indonesia. The results showed that organizational trust has not been a key driver to achieve the effectiveness of the implementation of education quality assurance policy in Indonesia, especially at Banggai Regency. Integrity, benevolence, and competence are important dimensions that need to be improved in creating organizational trust. The integrative model of organizational trust is proposed as a model that needs to be applied to improve the implementation network of education quality assurance policy in Indonesia.
\end{abstract}

Keywords: organizational trust; integrity; benevolence; competence; policy implementation network

\section{INTRODUCTION}

The study of trust has been extensively in various social science literature since decades ago, but the direct application of trust in overcoming inter-organizational problems in policy networks can be said to be relatively new [1]. Even in the theory of governance networks (governance networks) the role of trust is a neglected dimension in various public administration research. Whereas the role of trust is an important dimension for building better inter-organizational relationships, the creation of information exchange, awareness, and mutual support in meeting organizational resources, financial needs, and reducing conflict within the organization [2]. Therefore, this becomes very important in encouraging the successful implementation of public policy. As mentioned before, it can be stated that policy implementation is a complex process, because it often has to deal with various stakeholders and has diverse interests. The existence of this complexity is therefore necessary to apply trust in the organization [3], [4]. It can be shown in the implementation of the education quality assurance policy that has not shown the expected results. Based on the results of the Education for All Development Indonesia's (EDI) achievement survey, Indonesia is only at level 57 of 115 countries in the world by 2014 . The results of the Network for Education Watch Indonesia (JPPI) survey in 2016 showed that the index of education services in Indonesia is lower than the Philippines and Ethiopia. Similarly, the results of the Right to Education Index (RTEI) study measuring the quality of

Corresponding author: Alwi education in Indonesia seen from education governance, availability, accessibility, acceptability and adaptability indicators only reached $77 \%$. This result indicates that the quality of education in Indonesia has the same rank as State of Honduras and Nigeria. However, it is lower than the achievements of the Philippines (81\%) and Ethiopia $(79 \%)$ [5].

Nowadays, the implementation of the quality assurance of education and the improvement of the quality of primary and secondary education still faces various problems such as : (1) It is not fully socialized the National Education Standards as a reference to the quality of education; (2) the implementation of quality assurance and school improvement is still limited in monitoring the quality component in educational unit; (3) quality mapping is still in the form of unedited educational quality data collection from various education providers; and (4) follow-up of uncoordinated educational quality of data which were gathered from education providers and personnels at various levels.

The study mentioned above has concerned the strategy of implementation of quality assurance system by regency or city government. He found that the improvement of education quality is the responsibility of every component in educational unit. Improvement of quality in educational units cannot be achieved effectively, without a culture of quality in all components of the school. Improving the quality of education as a whole requires a special approach so that all components of the school have a quality culture [6]. Other studies have found that the transformation towards the quality of education in schools begins by adopting cooperation in improving the quality of education with school boards, administrators, staff, students, and teachers and the community [7].

The results of the study found that the implementation of education quality assurance system (EQAS) through Education Standard School (SSE) in SDN Cilandak Timur 08 Pagi South Jakarta has not run in accordance with the guidelines for the implementation of education quality assurance [8]. It has been found that the basic principle of applying a quality assurance model at the education unit level can be based on established benchmarking [9].

Some researches that have been done related to the implementation of the above policy ignore the aspect of organizational trust. Therefore, this study focuses on organizational trust in implementation network of education 
quality assurance policy. So then, an appropriate model of analyzing organizational trust within a network context is an integrative model of organizational trust. This model includes aspects of integrity, benevolence, and competence [10], network policy theory [11], perspective of government networks [2] explained that inter-organizational relationships are complex and trust can be a key driver that ensure to be developed in policy implementation. They argue that if the determinants of organizational trust are owned by trustors and trustees, so then it will create organizational trust, and also it can generate collaboration in determining some problems or risks, so it will achieve the expected outcomes ultimately [10]. The integrative model of building organizational trust is relevant to the theory of government networks that trust in governance networks will have a positive impact on the increased concerning to each actor who is involved in implementing policies, creating mutual exchange or assisting in addressing shortages power such as; human resources, financial support, reducing conflict, and there is a desire to minimize the risks that arise in policy implementation [2] Oganizational trust from the perspective of government networks means that trustors or trustees are able to work together [12], [13]. Based on the perspective above, if trust is established within among the trustor and trustee, it will have positive impact on the effectiveness of the policy implementation.

\section{RESEARCH METHOD}

This research uses qualitative approach with case study strategy [14]. It uses purposive sampling technique in determining informants. Those informants can be classified as follows: (1) Government officials included; (a) Head of Education and Culture Agency, and (b) Supervisor. (2) Nonexecutive agency, such as; (a) The Regional House of Representatives, (b) NGO, and (d) School Committee. The data collection technique applied in this research is observation, in depth interview, and documentation. Then, the data analysis process used was interactive models which are consisted of four stages: (a) Data collection. (b) Data reduction which is consisted of selections, abstractions, and categorizations, (c) Data presentations, and (d) Conclusions [12].

\section{RESULT AND DISCUSSION}

\section{A. Implementation of Education Quality Assurance Policy in Indonesia}

Quality education can be achieved with the involvement of all components of the nation, because national education is a shared responsibility among parents, government, and society and various parties, so it can develop to be a quality culture. Therefore, it requires a commitment and a common understanding in the implementation of education quality policy [13]. The results of the implementation of the quality assurance policy at the primary school, junior and senior high school education in Indonesia as measured from six National Educational Standards based on secondary data Performance Report of Ministry of Education and Culture, Directorate General of Basic and Secondary Education [10] as Table 1.
Implementation of education quality assurance policy can be said to be successful as proved from the achievement of Graduate Competency Standards (SKL) above 6.0. For content standards, process, assessment, teachers and personal education, and management are indicators that support the achievement of Graduate Competency Standards (SKL). As viewed from the achievements of SKL, it indicates that SKL of Basic Education that are Elementary School (ES) and Junior High School (JHS) has not been effective because the value achieved is less than 6.0. Meanwhile, at high school level, the achievement of SKL has exceeded SNP.

Table 1. Achievement of National Standards of Elementary and Secondary High School

\begin{tabular}{|c|c|c|}
\hline \multicolumn{3}{|c|}{ Elementary and Secondary High School } \\
\hline National Educational Standards & ES & SHS \\
\hline $\begin{array}{c}\text { Graduate Competence } \\
\text { Standards }\end{array}$ & 5.05 & 4.95 \\
\hline Content Standards & 5.81 & 7.21 \\
\hline Process Standards & 5.49 & 5.50 \\
\hline Assessment Standards & 6.65 & 6.76 \\
\hline $\begin{array}{c}\text { Educators and Personal } \\
\text { Education Standars }\end{array}$ & 6.44 & 6.49 \\
\hline $\begin{array}{c}\text { Management Standards } \\
\text { National Educational Standards } \\
\text { (NES) }\end{array}$ & 6.67 & 6.75 \\
\hline Source: Directorate General of Basic and Secondary Eduction, 2016 \\
\hline
\end{tabular}

Nevertheless, in general the achievement of the implementation of education quality assurance policy in Indonesia can be said to be ineffective because there are still many problems to be solved to achieve the optimal SNP or exceed the target of SKL achievement above 6.0. Beside that there is a wide gap between marginal areas and poorer people in getting quality education than the richness ones. Thus, it can be argued that the quality assurance system of education based on national education standards (SNP) is less effective.

\section{B. Organizational Trust In the implementation of Education Quality Assurance Policy in Banggai Regency}

\section{Integrity}

In this research, integrity can be defined as honest and responsible attitude that is shown by trustor and trustee in implementing quality assurance policy of education so that it will be created the highest organizational trust. Based on the results, actors' integrity has not been effective to create organizational trust in policy implementation networks. It could be seen from the fact that integrity of the officials responsible for the implementation of this policy has not been realized. It is indicated by information stated by informants who are the Education Board, The Regional House of Representatives, NGO, and the School Committee, revealing that the actor's integrity has not been effective in building trust in the implementation of the education quality assurance policy. The Regulation of the Minister of Education and Culture No. 63, year 2016 about the Quality Assurance System of Primary and Secondary Education states that the program is an integrated element consisting of organizations, policies and integrated processes that regulate all activities to improve the quality of basic and secondary education systems that interact in a systematic, planned and sustainable manner 
(Article 1, paragraph 4). This regulation clearly states that the quality assurance of education requires collaborative efforts, the unity of elements consisting of integrated organizations, policies and processes. To implement the policy, there has been a fact of integrity in the quality of education assurance between Education Office Personnel of Banggai Regency and Education Board, but in practice this has not been applied effectively.

The Education Board and the School Committee explained that the integrity of policy actors is still lacking due to the fact that the integrity of the education quality assurance service that is signed together is not applied openly and evenly to all regions in this regency. Therefore, it is important to create the integrity of actors in the implementation of education quality assurance policy by applying mutual agreement among all stakeholders involved. The result of this study is shown in the following table:

Table 2. Response of Government and Non-executive agency toward the integrity of Education Board

\begin{tabular}{|c|c|c|c|c|}
\hline \multirow[b]{2}{*}{ Aspects } & \multicolumn{4}{|c|}{ Informants } \\
\hline & $\begin{array}{c}\text { Government } \\
\text { Agency }\end{array}$ & $\begin{array}{c}\text { The Regional } \\
\text { House of } \\
\text { Representatives }\end{array}$ & NGO & $\begin{array}{c}\text { School } \\
\text { Committee }\end{array}$ \\
\hline Commitment & $\begin{array}{l}\text { - Integrity fact } \\
\text { applied } \\
\text { - Credibility of } \\
\text { actors }\end{array}$ & $\begin{array}{l}\text { - Integrity fact } \\
\text { focused } \\
\text { - Task } \\
\text { performance }\end{array}$ & $\begin{array}{l}\text { - Integrity fact } \\
\text { applied } \\
\text { - Task } \\
\text { performance }\end{array}$ & $\begin{array}{l}\text { - Integrity fact } \\
\text { obedient } \\
\text { - Task } \\
\text { performance }\end{array}$ \\
\hline Consistency & $\begin{array}{l}\text { - Education quality } \\
\text { standards } \\
\text { - Monitoring } \\
\text { - Evaluation } \\
\end{array}$ & $\begin{array}{l}\text { - Education } \\
\text { standards focused } \\
\text { - Behavior based } \\
\text { norm } \\
\end{array}$ & $\begin{array}{l}\text { - Advisory roles } \\
\text { - Education } \\
\text { quality } \\
\text { Standards } \\
\end{array}$ & $\begin{array}{l}\text { - Advisory roles } \\
\text { - Supporting } \\
\text { roles }\end{array}$ \\
\hline Responsibility & $\begin{array}{l}\text { - Task focused } \\
\text { - Role of Enhancing } \\
\text { Graduate } \\
\text { Competency } \\
\text { Standards }\end{array}$ & $\begin{array}{l}\text { - Task applied } \\
\text { - Graduate } \\
\text { competency } \\
\text { standards }\end{array}$ & $\begin{array}{l}\text { - Enhancing } \\
\text { Graduate } \\
\text { Competency } \\
\text { Standards }\end{array}$ & $\begin{array}{l}\text { - Mediating } \\
\text { agency of } \\
\text { education } \\
\text { - Maintaining } \\
\text { the Graduate } \\
\text { Competency } \\
\text { Standards }\end{array}$ \\
\hline
\end{tabular}

In this research, integrity is defined as an action of Education Board actors with the relevant moral behavior that consists of commitment, consistency, and credibility of actors in applying the integrity pacts of education quality assurance policy at Banggai Regency.

Integrity violations can be defined as violations of these moral values and norms... integrity has defined as acting in agreement with the relevant moral values, standards, norms, and rules, meaning that the research will focus on manifestations of behavior rather than intentions or underlying values [18].

Several studies have shown that integrity can create openness, honesty, and responsibility towards the achievement of organizational goals. Integrity is a main component of organizational trust, so then it cannot be separated in an effort to create organizational trust. In addition, integrity is required to meet public expectations in delivering quality education. In this study, integrity is less effective. The results are consistent with the results of research that has been done, indicating that low integrity affects the effectiveness of public confidence. Integrity is necessary because it can fully create an organizational trust towards the achievement of organizational goals. Integrity is closely related to organizational trust because trust is the perception of a given person to implement ethical principles that are seen as the most fundamental foundation in fostering inter-organizational cooperation relations in achieving goals [19].

Based on that theory and the data analysis which is shown on Table 2, it can be elaborated that, in this research, the dimension of integrity can be seen from three aspects namely: commitment, consistency, and credibility.

In the Regulation of the Minister of Education and Culture Number 63 of 2016 about the Quality Assurance System of Primary and Secondary Education stated that the Quality Assurance System of Primary and Secondary Education is an integrated element consisting of organizations, policies and integrated processes that regulate all activities to improve the quality of basic and secondary education systems that interact in a systematic, planned and sustainable behavior.

This study showed that the integrity of actors needs to be improved because it is a very important thing to determine the success of implementation of education quality assurance policy.

\section{Benevolence}

The theory of organizational trust states that benevolence is a positive perception of actors seeking to accept the actions of a person or individual that is useful in trust. There is a relationship towards goodwill between groups to achieve goals within the organization [10], [20].

"Trust-based adherence" where an individual will not intend to destroy the other when given the opportunity to take the same action [25]. Basically, benevolence is a trust dimension depicted as willingness to support the trustor in every activity [22], [10]. Benevolence is often equated with the term in religion as empathy [23]. Benevolence is the highest form of value and affirms that benevolence is a primary basis of wishes on the other actors for building organizational trust. If benevolence is not provided, all other values can turn to be harmful for any relationship"[20].

Benevolence is an understanding and acceptance of the legitimacy that is given for the benefit of others and necessarily requires empathy of either trustor or trustee to enhance the benefit of life together [10]. By the adherence of actors involved in the implementation network of education quality assurance policy in Banggai District, it can be said that commitment and consistency are fundamental aspects in supporting the policy of quality assurance of education. The result of benevolence in implementation of education quality assurance policy at Banggai Regency is illustrated in following table:

Table 3. Response of Government and Non-executive agency toward the benevolence of Education Board

\begin{tabular}{|c|c|c|c|c|}
\hline \multirow{2}{*}{ Aspects } & Government Agency & $\begin{array}{c}\text { The Regional } \\
\text { House of } \\
\text { Representatives }\end{array}$ & NGO & $\begin{array}{c}\text { School } \\
\text { Committee }\end{array}$ \\
\cline { 2 - 5 } & $\begin{array}{c}\text { Participate in } \\
\text { Supporting education }\end{array}$ & $\begin{array}{c}\text { Supported } \\
\text { education quality }\end{array}$ & $\begin{array}{c}\text { Maintain education } \\
\text { quality }\end{array}$ & $\begin{array}{c}\text { Support human } \\
\text { resources of } \\
\text { education }\end{array}$ \\
\hline Willingness & Formulate program & $\begin{array}{c}\text { Program of } \\
\text { quality assurance }\end{array}$ & $\begin{array}{c}\text { School } \\
\text { effectiveness }\end{array}$ & $\begin{array}{c}\text { Supporting } \\
\text { program }\end{array}$ \\
\hline Openess & $\begin{array}{c}\text { Coordination and } \\
\text { communication }\end{array}$ & $\begin{array}{c}\text { Cordination and } \\
\text { communication } \\
\text { of actors }\end{array}$ & $\begin{array}{c}\text { Sincronization } \\
\text { program }\end{array}$ & $\begin{array}{c}\text { Corate good } \\
\text { coordination and } \\
\text { participation in } \\
\text { education }\end{array}$ \\
\hline
\end{tabular}

Source: Data reduction, 2017 
In this research, benevolence is defined as the behavior of actors to hold the program of education quality assurance which involved altruism, willingness, and openness. Benevolence has two important determinants to create an organizational trust i.e. caring and openness [24]. Education policies that are conducted tend to be more physical established rather than non-physical programs such as improving the learning process, improving the quality of teachers and education management standards.

All parties in order to comply with government regulations on education quality assurance system governing the implementation of the education quality assurance policy. The government agency stated that actually regulations on the quality system of primary and secondary education have been set by the central government, but still less integrated in applying the rules. This is due to the lack of coordination and communication between actor to do the programs.

Based on the result of this research, it can be confirmed that the benevolence of actors in achieving the organizational trust in the implementation of education quality assurance policy is still ineffective.

\section{Competence}

Competence is seen as the ability of various schools of thought from various fields of science. In the organizational science theory, competence is a combination of knowledge, skills, education, social skills, and behaviors applied to improve performance [25], [26]. A more general view, competence is an adequate level or quality or something of a certain qualification, and has the ability to show quality work in accordance with its role. Therefore, competence is an integral part that determines a trustee can show the work that is realized in the form of action or no results at all [21].

Based on the theories above, this study can define that competence is a set of capabilities owned by trustor or trustee that includes knowledge, skills, education, social skills, behavior that shows performance, action directed, personal quality, and certain actions expected to trustee, willingness to show the quality of work in the implementation of education quality assurance policy. The result of competence in this research can be seen in the following table:

Table 4. Response of Government and Non-executive agency toward the competence of Education Board

\begin{tabular}{|l|l|l|l|l|}
\hline \multirow{2}{*}{ Aspects } & \multicolumn{4}{|c|}{ Informants } \\
\cline { 2 - 5 } & $\begin{array}{l}\text { Government } \\
\text { Agency }\end{array}$ & $\begin{array}{l}\text { The Regional } \\
\text { House of } \\
\text { Representatives }\end{array}$ & NGO & $\begin{array}{l}\text { School } \\
\text { Committee }\end{array}$ \\
\hline Expertise & $\begin{array}{l}\text { Knowledge and } \\
\text { Understanding } \\
\text { of education } \\
\text { problems }\end{array}$ & $\begin{array}{l}\text { Education } \\
\text { quality solution }\end{array}$ & $\begin{array}{l}\text { Expert in } \\
\text { Education }\end{array}$ & $\begin{array}{l}\text { Understanding } \\
\text { education } \\
\text { completely }\end{array}$ \\
\hline \multirow{4}{*}{ Skillful } & $\begin{array}{l}\text { Mastering } \\
\text { education } \\
\text { quality } \\
\text { systematicly }\end{array}$ & $\begin{array}{l}\text { Education } \\
\text { Technology }\end{array}$ & $\begin{array}{l}\text { Information } \\
\text { Sistem } \\
\text { technology } \\
\text { education } \\
\text { management }\end{array}$ & $\begin{array}{l}\text { Supporting } \\
\text { Education } \\
\text { System of } \\
\text { information and } \\
\text { Management }\end{array}$ \\
\hline \multirow{5}{*}{ Professionalism } & $\begin{array}{l}\text { Share } \\
\text { knowledge } \\
\text { about } \\
\text { quality } \\
\text { assurance } \\
\text { policy }\end{array}$ & $\begin{array}{l}\text { Guiding } \\
\text { education } \\
\text { quality } \\
\text { assurance } \\
\text { completely }\end{array}$ & $\begin{array}{l}\text { Achievement } \\
\text { of Education } \\
\text { Quality } \\
\text { Assurance }\end{array}$ & $\begin{array}{l}\text { Education } \\
\text { social } \\
\text { participation }\end{array}$ \\
\hline
\end{tabular}

Source: Data reduction, 2017
The importance of competence in the organization can be seen from the argumentation that "situations where competence is required a trustor might be less likely to develop trust toward trustee, if he or she is incompetent and thus technically unable to perform the necessary action" [21].

The professionalism of actors still needs to be improved through workshop and socialization or training of quality assurance system of primary and secondary education. In this case, based on the interview revealed that the actors have not understood the program as whole. On the other hand, to bring this program to be succeeded, it needs the support of public agency as a systematic relationship.

However, the fact that the competences of actors in carrying out the policy implementation are necessary and to be the key engine to achieve the organization goals.

\section{Research Discussion}

The result of data analysis by using integrative analysis model confirmed that the organizational trust in implementing the education quality assurance has not been carry out effectively. This research consistent with the previous research that has been elaborated in the early description, such as in improving the quality of education as a whole that requires a special approach so that all components of the school have a quality culture [6], transformation towards the quality of education in schools [7], the implementation policy need some technical and substantive constraints [8], and the implementation stage at the level of education unit so that it can all run synergistically and simultaneously.

Based on the organizational trust literature in public administration, organizational trust should pay attention seriously to employees' trust attitude and motivation [39], trust in government [28];[29], process and output of government [30];[31], and the organizational trust from the varieties of trust [32; [33]; [34].

Another research that is consistent with this research concerned with the organizational trust in public organization by using dimension organizational trust, such as; integrity $[35] ;[36] ;[10] ;[26]$; benevolence [22];[37];[38], role of competences [39]; [26];[25] in which their research found that integrity, benevolence, and competences were necessary to determine the achievement of organizational trust effectively, especially on the implementation of education quality assurance policy. This study is consistent also with the organizational trust model [10];[20];[25].

Understanding the role of integrity and trust at an individual and organizational level is metrics to build the absolute standard of what a great workplace is. Integrity, as a measure of coherence and consistency, is key to establishing and sustaining trust [40].

Competence promotes organizational trust. A successful organization with an admired reputation contributes to a positive sense of self for its employees. As organizations have come to rely less on structures and formal arrangements and more on collaboration and cooperation inside and outside the 
firm, new emphasis is given on trust as one of the fundamental motors of these processes. If trust is absent, no one will risk moving first and all will sacrifice the gains of collaboration and cooperation. [41].

\section{The Limitation and the Future of Research}

During the study, the limitations found were mainly concerned with the dimension of organizational trust which is complicated and complex. Based on the organizational trust literature which concerned to the integrative model of organizational trust, creating the organizational trust can be seen from three main dimensions namely, integrity, benevolence, and competences. While another expert showed that there are many dimensions of organizational trust that can be seen from several aspects of integrity, benevolence, attention, competence, openness, reliability, and intensions [10]. Another theory about organizational trust argued that interpersonal and inter-organizational trusts contribute positively to organizational trust as an important part in ensuring organizational success in achieving goals [42].

Based on the perspective of governance networks, trust in governance networks will have a positive impact on the increased concern of each actor involved in implementing policies, the creation of mutual exchange of information, together to overcome the lack of resources includes, human resources, financial support, reducing conflict, and there is a desire to minimize the risks that arise in policy implementation [2]. Therefore, it can be argued that implementation networks have been necessary in democratic public service [43].

Meanwhile, this research has been used the one model of organizational trust in creating an organizational trust which is very important dimensions, consisting only three dimensions such as: integrity, benevolence, and competence. So, for future research, creating organizational trust in policy implementation can be added to some dimensions to create organizational trust in public organization by using interpersonal trust and inter-organizational to build the organizational trust in public organizations.

\section{CONCLUSION}

The organizational trust in the implementation network of education quality assurance policy in Indonesia especially in Banggai Regency has not been effective yet. This can be revealed from three dimensions of organizational trust. The first is integrity of the actors that has not been optimum in implementing education quality assurance policy. The dimensions of benevolence and competence of actors were still lower. Therefore, it requires serious efforts of actors which whom involved in the implementation network of education quality assurance policy must improve the integrity, benevolence, and competence.

Based on this research, it shows that organizational trust is very important dimension in implementation networks to achieve a high benefits of education quality assurance. It can also support actors in public organization to achieve the high effectiveness in policy implementation. Three dimensions that must be applied to create organizational trust in implementation networks of education quality assurance policy included integrity that has three aspects i,e. commitment, consistency, and responsibility. The dimension of benevolence needs to create the organizational trust which consists also three main aspects such as; altruism, willingness, and openness. Meanwhile, the competence of actors in the implementation networks of education quality assurance policy is necessary to make the program more effective. In this research, competence of actors to create an organizational trust is expertise, skillful, and professionalism.

\section{REFERENCES}

[1] R. Rusu and A. Babos. "Organizational Trust Between Institutional And Interpersonal Trust," Scientific Bulletin, De Grueter, Vol.XX No 2, 2015, pp. 55-60.

[2] E.H. Klijn and J. Koppenjan, "Governance Networks In The Public Sector,",Routledge, London. 2016

[3] C. Argyris, Integrating the Individual and the Organization. In Ning, L, Jin, Y., \& Mingxuan, J., How does organizational trust benefit work performance? Higher Education Press and Springer-Verlag, Vol. 1, No 4, 2007, pp. 622-637.

[4] K.T. Dirks and D.L. Ferrin. "Trust in leadership: Meta-analytic findings and implications for research and practice," Journal of Applied Psychology, Vol. 87, 2002, pp. 611-628.

[5] W.C. Smith and T. Baker, "Right to Education Index (RTEI)," 2017, RESULTS Educational Fund.

[6] Moerdiyanto, "Implementation Strategy of Educational Quality Assurance System (SPPMP) By District / City Government “ (Strategi Pelaksanaan Sistem Penjaminan Mutu Pendidikan (SPPMP) Oleh Pemerintah Kabupaten/Kota, 2012). http://staff.uny.ac.id/penelitian/ (Accessed on 31 August, 2017).

[7] D.P.Yuniar, D.P., Improving the Quality of Education with the Concept of "Full Day School", Proceedings of the National Seminar on Repositioning Full Day School Formal, Nonformal, and Informal Education (Peningkatan Mutu Pendidikan dengan Konsep "Full Day School”, Prosiding Seminar Nasional Repositioning Full Day School Pendidikan Formal, Nonformal, Dan Informal), Malang, 22-23 Okt. 2016, Ollino Garden Hotel, Malang. 2016

[8] M. Mauluddin and AYS. Rahayu. "Analysis of Implementation of Education Quality Assurance System (SPMP) through School Self Evaluation (EDS) at SDN Cilandak Timur 08 Pagi South Jakarta", (Analisis Pelaksanaan Sistem Penjaminan Mutu Pendidikan (SPMP) melalui Evaluasi Diri Sekolah (EDS) di SDN Cilandak Timur 08 Pagi Jakarta Selatan), Jurnal Ilmu Administrasi Negara, FISIP UI, 2013, Jakarta.

[9] M.A.Marhabang, "Optimizing the Quality Assurance Model of Education at Education Unit Level" (Optimalisasi Model Penjaminan Mutu Pendidikan pada Tingkat Satuan Pendidikan" E-Buletin Media Pendidikan LPMP Sulsel, 2015, ISSN.2355-3189.

[10] R.C.Mayer; J.H. Davis and F.D. Schoorman, "An integrative model of organizational trust,” Academy of Management Review, Vol. 20, 1995. pp. 709-734.

[11] R. Keast; M.P. Mandell and R. Agranoff, "Network Theory in the Public Sector: Building New Theoretical Frameworks," 2014. Routledge, London.

[12] J.W. Driscoll "Trust and participation in organizational decision making as predictors of satisfaction," Academy of Management Journal, Vol. 21, 1978, pp. 44-56.

[13] D. Scott The causal relationship between trust and the assessed value of management by objectives," Journal of Management, Vol. 6, 1980, pp. 157-175.

[14] R.K. Yin., "Case Study Research: Design and Methods, $4^{\text {th }}$ Eds., 2009, SAGE Publication Inc. Thousand Oaks, California.

[15] M.B. Miles and A.M. Huberman, "Qualitative Data Analysis: An Expanded Sourcebook,” 1994, SAGE Publication, Inc, New York. 
[16] Ministry of Education and Culture of the Republic of Indonesia., "Training on Human Resource Development Quality Assurance," Ministry of Education and Culture of the Republic of Indonesia (Kementerian Pendidikan dan Kebudayaan Republik Indonesia., Diklat Pengembangan SDM Penjaminan Mutu Pendidikan) 2012, Jakarta.

[17] Directorate General of Basic and Secondary Education, Ministry of Education and Culture, "Academic Paper Draft Regulation of the Minister of Education and Culture on Quality Assurance of Primary and Secondary Education" (Naskah Akademik Rancangan Peraturan Menteri Pendidikan dan Kebudyaan Tentang Penjaminan Mutu Pendidikan Dasar dan Menengah), 2016, Jakarta.

[18] E. Kolthoff; R.W.Cox III and T. Johnson. "Measuring Integrity A Dutch-American Comparative Project". In Cox III, R.W., "Ethics and Integrity in Public Administration Concepts and Cases," 2009, M.E.Sharpe

Armonk, New York, Business Park Drive.

[19] J.K Butler, "Toward understanding and measuring conditions of trust: Evolution of A conditions of trust inventory," Journal of Management, Vol.17, 1991, pp. 643-663.

[20] J.K Muhl. "Organizational Trust: Measurement, Impact, and the Role of Management Accountants," 2014, Springer, London.

[21] D.Z. Levin; R. Cross; L.C. Abrams, "Trust and knowledge sharing: a critical combination," IBM Institute for knowledge based organizations, USA, 2002, pp 1-7.

[22] P.M Doney and J.P Cannon, "An examination of the nature of trust in buyer-seller relationships," J. Mark, Vol. 61, 1997, pp. 35-51.

[23] S.G. Black, "Trust and commitment: reciprocal and multidimensional concepts in distribution relationships," Texas A\&M University-Corpus Christi. Journal, 2008, pp 46-53.

[24] A.K.Mishra "Organizational Responses To Crisis: The Centrality of Trust”. In Kramer, Roderick M. and Thomas Tyler (eds.) Trust In Organizations. Newbury Park, CA: Sage. 1996. pp.261-287.

[25] B. Nooteboom, and F. Six, "The Trust Process in Organizations Empirical Studies of the Determinants and the Process of Trust Development," 2003, Edward Elgar, USA.

[26] D.Z. Levin; R.Cross; R., Abrams L.C, and E. Lesser. "Nurturing interpersonal trust in knowledge-sharing networks," Acad Manage Exec, Vol. 17, Number 4, 2003, pp. 64-76.

[27] K. Jones, "Trust: Philosophical Aspects," The University of Melbourne, Parkville, VIC, Australia, 2015, Elsevier Ltd.

[28] T. Christensen and P. Laegreid," "Trust in government the relative importance of service satisfaction, political factors and demography," Public Performance and Management Review, Volume 28, Number 4, 2014, pp.487-511.

[29] J. Marlowe "Part of the solution or cogs in the system? The origins and consequences of trust in public administrators," Public Integrity, Vol. 6, No. 2, 2004, pp. 93-113.

[30] G.G. Van Ryzin. "Outcomes, process, and trust of civil servants," Journal of Public Administration Research and Theory, Vol. 21, No. 4, 2011, pp. 745-760.

[31] E. Vigoda-Gadot, "Citizens' perceptions of politics and ethics in public administration: A five-year national study of their relationship to satisfaction with services, trust in governance, and voice orientations," Journal Public
Administration Research and Theory, Vol.17, No. 2, 2007. pp. 285-305.

[32] S. Kim, "Public trust in government in Japan and South Korea: Does the rise of critical citizens matter?" Public Administration Review, Vol. 70, No. 5, 2010, pp. 801-810.

[33] S. Van de Walle, S., Van Roosbroek, S., and Bouckaert, G., "Trust in the public sector: Is there any evidence for a long-term decline?" International Review of Administrative Sciences, Volume 74, Number 1, pp. 45-62.

[34] E. Vigoda-Gadot; A. ShohamG. and Vashdi, D.R., "Bridging bureaucracy and democracy in Europe: A comparative study of perceived managerial excellence, satisfaction with public services, and trust in governance," European Union Politics, Vol. 11, No. 2, 2010, p. 289.

[35] G. Dietz and Hartog, "Measuring trust inside organizations," Personnel Rev, Emerald, Journal Vol.35, 2006, pp. 557-588.

[36] G.M Spreitzer and A.K Mishra., Giving up control without losing control trust and its substitutes' effects on managers' involving employees in decision making, In Muhl, J.K., "Organizational Trust: Measurement, Impact, and the Role of Management Accountants," 2014, Springer, London.

[37] J. Zhou; J Lopez , R, Deng R, and F. Baso," Information security, 8th international conference," ISC 2005, Singapore, September 20-23, 2005, Proceedings, lecture notes in computing, science, p 483.

[38] S.G. Black., Trust and commitment: reciprocal and multidimensional concepts in distribution relationships, Texas A\&M University-Corpus Christi. Journal, 2008, pp 46-53.

[39] S.P. Shapiro.,"The Social Control of Impersonal Trust," American Journal of Sociology, Vol. 93, No. 3, 1987, pp. 623-658.

[40] Shahid, A., "Integrity \& Trust: The Defining Principles of Great Workplaces," Journal of Management Research, Vol. 5, No. 4, 2013, pp. 64-75.

[41] Margolis, S., Organizational Trust, https:// sheilamargolis. Com, 2017. (Accesed $4^{\text {th }}$ October, 2017)

[42] Bachmann, R., and Inkpen, A.C., "Understanding Institutional- based Trust Building Processes in Inter-organizational Relationships," Organization Studies, SAGE, London, Vol. 32, No 2, 2011, pp.281 301.

[43] Alwi, M., "Network Implementation Analysis on Democratic Public Service", 2010. International Journal of Administrative Science \& Organization. 